\title{
PELATIHAN PENGELOLAAN KEUANGAN BADAN USAHA MILIK DESA DI KABUPATEN LOMBOK BARAT
}

\author{
Siti Atikah*), Wirawan Suhaedi, Baiq Rosyida dan Intan Rakhmawati \\ Jurusan Akuntansi, Fakultas Ekonomi dan Bisnis, Universitas Mataram \\ Jl. Majapahit 62, Mataram 83125, Lombok - Indonesia \\ ${ }^{*}$ Korespondensi: siti.atikah@unram.ac.id
}

\begin{abstract}
ABSTRAK
Salah satu amanat Undang-Undang nomor 6 tahun 2014 mengenai Desa adalah meningkatkan kesejahteraan masyarakat desa. Amanah ini diterapkan melalui pendirian Badan Usaha Milik Desa (BUMDes). BUMDes berkewajiban untuk menyusun laporan keuangan. Tingkat kesulitan BUMDes dalam menyusun laporan keuangan diantaranya adalah ketrampilan sumber daya manusia. Kegiatan pengabdian kepada masyarakat ini bertujuan untuk meningkatkan pengetahuan dan ketrampilan teknis para pengelola BUMDes dalam menyusun laporan keuangan yang sesuai dengan Standar akuntansi Keuangan Entitas Kecil, Mikro dan Menengah (SAK-EMKM). Kegiatan pengabdian kepada masyarakat ini memberikan materi pelatihan yang meliputi sistem akuntansi, persamaan dasar akuntansi, jurnal umum, buku besar, buku pembantu serta laporan keuangan. Hasil dari kegiatan ini adalah peningkatan pemahaman para peserta mengenai konsep dasar akuntansi, penggunaan kode akun dan pemahaman persamaan dasar akuntansi menggunakan lima jari.
\end{abstract}

Kata Kunci: badan usaha milik desa, laporan keuangan, kabupaten lombok barat.

\section{PENDAHULUAN}

Sejalan dengan diterapkannya

Undang-Undang nomor 6 tahun 2014

mengenai Desa, desa memiliki

kewenangan untuk menyelenggarakan

urusan pemerintah desa dan

melaksanakan pembangunan desa,

pembinaan dan pemberdayaan

masyarakat desa menuju masyarakat yang sejahtera. Undang-undang ini menetapkan bahwa desa berperan sebagai subyek pembangunan desa. Kesejahteraan masyarakat desa ditentukan sendiri oleh masyarakatnya. Pendirian Badan Usaha Milik Desa (BUMDes) sebagai salah satu wadah untuk meningkatkan kesejahteraan masyarakat desa. 
BUMDes diharapkan dapat menjadi mesin penggerak ekonomi masyarakat (Putra, 2015). Sebagai penggerak ekonomi, pengelola BUMDes diharapkan dapat memenuhi kewajibannya, antara lain menyusun laporan keuangan. Berdasarkan laporan keuangan inilah akan ditentukan kinerja keuangan, volume usaha BUMDes, serta jumlah yang akan bagikan kepada para pemberi modal sebagai bagi hasil ke pemerintah desa atau hasil usaha desa.

BUMDes telah dibangun di berbagai desa. Usaha BUMDes yang telah berdiri antara lain: jasa salon, penyewaan terop dan kursi, jasa simpan pinjam dan warung serba ada (Putra, 2015). Ada yang mengelola satu jenis usaha, ada pula yang mengelola lebih dari satu jenis usaha. Pasal 26 Peraturan Menteri Desa, Pembangunan Daerah Tertinggal dan Transmigrasi Republik Indonesia Nomor 4 tahun 2015 menyatakan bahwa hasil usaha BUMDes dapat dibagikan sesuai dengan ketentuan yang disepakati dalam Anggaran Dasar/Anggaran Rumah Tangga
BUMDes. Dengan adanya pembagian ini, tentunya, pengelola BUMDes wajib menyusunkan sistem akuntansi yang memadai.

Sistem akuntansi yang memadai dalam menyusun laporan keuangan antara lain meliputi penyusunan kode akun, nama akun, buku jurnal umum, buku kas, buku bank, buku piutang, buku barang, dan neraca saldo. Dalam proses penyusunan laporan keuangan ini, BUMDes juga perlu menentukan kebijakan akuntansi yang dianut. Kebijakan akuntansi yang akan dipilih tersedia dalam Standar Akuntansi Keuangan untuk Entitas Mikro, Kecil dan Menengah (SAK-EMKM) yang diterbitkan oleh Ikatan Akuntan Indonesia (2016).

Pengelola BUMDes telah berupaya melaporkan tanggungjawabnya melalui laporan keuangan. Salah satu contoh laporan yang disusun oleh salah satu BUMDes tampak dalam tabel 1.

Tabel 1. Contoh Laporan yang Telah Disusun

\begin{tabular}{|l|l|}
\hline \multicolumn{2}{|l|}{ Penerimaan } \\
\hline I & $\begin{array}{l}\text { Uang dari Bendahara Desa } \\
(3 / 6 / 2017)\end{array}$ \\
\hline
\end{tabular}




\begin{tabular}{|c|c|}
\hline II & $\begin{array}{l}\text { Penyertaan modal dari desa } \\
(13 / 10 / 2017)\end{array}$ \\
\hline \multirow[t]{2}{*}{ III } & $\begin{array}{l}\text { Laba usaha } \\
\begin{aligned} & \text { 1. } \text { Konsumsi sarasehan } \\
& \text { sumpah pemuda } \\
& \text { 2. } \text { Konsumsi acara } \\
& \text { rebopungkasan } \\
& \text { 3. } \text { Penjualan pulsa } \\
& \text { 4. } \text { Pembayaran listrik PLN } \\
& \text { 5. } \text { Konsumsi rapat BPD } \\
& \text { 6. } \text { Konsumsi jalan sehat dsn } \\
& \text { jejeran }\end{aligned}\end{array}$ \\
\hline & Total penerimaan \\
\hline \multicolumn{2}{|c|}{ Pengeluaran } \\
\hline I & $\begin{array}{ll}\text { Renovasi kantor } \\
\text { 1. } & \text { Folding gate } \\
\text { 2. } & \text { Akses jalan } \\
\end{array}$ \\
\hline II & $\begin{array}{ll}\text { Peralatan kantor } \\
\text { 1. } & \text { Printer } \\
\text { 2. } & \text { Laptop } \\
\text { 3. } & \text { Modem } \\
\text { 4. } & \text { Stamp } \\
\text { 5. } & \text { Nota usaha } \\
\end{array}$ \\
\hline III & $\begin{array}{ll}\text { Perabot kantor } \\
\text { 1. } & \text { Kursi kerja } \\
\text { 2. } & \text { Kipas angina } \\
\text { 3. } & \text { Kursi tamu }\end{array}$ \\
\hline IV & $\begin{array}{l}\text { Promosi } \\
\text { 1. Spanduk bumdes } \\
\text { 2. Label dus snack }\end{array}$ \\
\hline V & $\begin{aligned} & \text { Pengeluaran lain-lain } \\
& \text { 1. } \text { Honor pembuatan } \\
& \text { siteplan desa } \\
& \text { 2. } \text { Konsumsi tamu ke } \\
& \text { bumdes } \\
&\end{aligned}$ \\
\hline & Total pengeluaran \\
\hline
\end{tabular}

Upaya pengelola BUMDes

untuk menyusun laporan keuangan perlu diacungi jempol. Namun, laporan yang disusun dalam tabel 1 memerlukan beberapa perbaikan, agar sesuai dengan kaidah-kaidah yang dikandung dalam laporan keuangan.
Faktor ketrampilan sumber daya manusia (SDM), peraturan yang cepat berubah atau bertambah, serta umur BUMDes yang relatif masih baru, diprediksi sebagai pemicu belum dapat disusunnya laporan keuangan dengan baik. Kegiatan pengabdian masyarakat ini bertujuan meningkatkan pengetahuan dan ketrampilan teknis pengelola BUMDes dalam menyusun laporan keuangan yang sesuai dengan SAK-EMKM (Ikatan Akuntan Indonesia, 2016).

\section{METODE KEGIATAN}

Kegiatan ini dilaksanakan selama 6 (enam) bulan, dari bulan April sampai dengan September 2018 di Kabupaten Lombok Barat. Kegiatan ini diawali dengan koordinasi waktu, tempat dan peserta melalui pendamping BUMDes. Pelatihan dilaksanakan dengan metode diskusi partisipatif mengenai penyusunan laporan keuangan. Peserta yang hadir merupakan pengelola BUMDes yang ada di Kabupaten Lombok Barat, khususnya penanggungjawab keuangan. Peserta yang hadir berasal dari desa: Ombe Baru, Lelede, Sesela, 115

Available online : http://abdiinsani.unram.ac.id 
Gontoran, Dasan Baru, Banyumulek

Suasana "sersan" yang dan Ombe Rerat. Adapun materi yang disampaikan meliputi konsep dasar dibangun sebagai awal memulai memahami proses penyusunan sistem akuntansi, jurnal umum, buku besar dan buku pembantu, persamaan dasar akuntansi serta penyusunan laporan keuangan berdasarkan Standar Akuntansi Entitas Kecil dan Menengah (SAK EMKM).

\section{HASIL DAN PEMBAHASAN}

$\begin{array}{lr}\text { Kegiatan } & \text { pengabdian } \\ \text { masyarakat, yaitu } & \text { pelatihan }\end{array}$
penyusunan laporan keuangan bagi pengelola BUMDes dilaksanakan di ruang pertemuan kantor desa Ombe Baru Kecamatan Kediri Kabupaten Lombok Barat. Suasana pelatihan yang "sersan", serius tapi santai, tampak pada gambar 2 berikut.

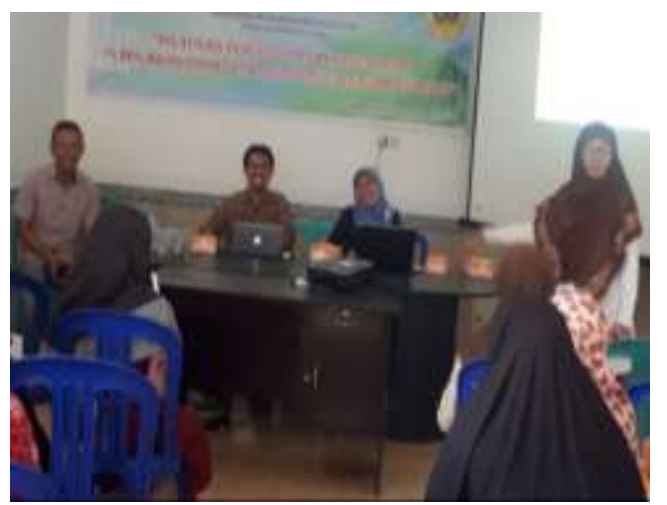

Gambar 1. Suasana ringan dan santai diawal pelatihan yang dibangun pemateri laporan keuangan. Sesungguhnya, penyusunan laporan keuangan bagi pengelola BUMDes tidak mudah dan tidak sulit. Mengapa? Tidak sulit, karena format laporan keuangan sudah tersedia, bahkan sudah tersedia juga aplikasi keuangan khusus BUMDes. Peserta yang hadir juga memiliki pengalaman dalam mengelola keuangan BUMDes, sehingga memiliki interaksi dua arah yang baik. Namun juga tidak mudah. Hal ini disebabkan kemampuan memahami konsep dasar tertentu, seperti konsep "matching cost against revenue"atau prinsip penandingan biaya dengan pendapatannya (Ikatan Akuntan Indonesia, 2016). Tidak mudah pula bagi tim pengabdian untuk mengenalkan dasar-dasar akuntansi, karena peserta berasal dari berbagai BUMDes dengan jenis usaha yang beragam. Kesungguhan peserta memahami materi tampak pada gambar 2. 


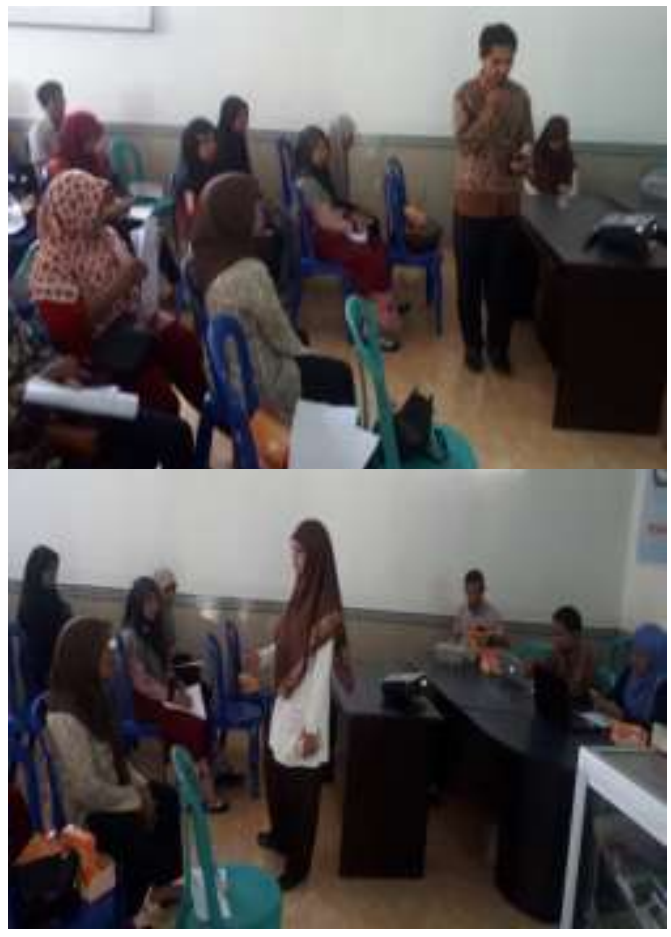

Gambar 2. Keseriusan peserta saat mendengarkan pemaparan materi

Salah satu yang dikenalkan oleh tim pengabdian adalah persamaan dasar akuntansi menggunakan lima jari (Warsono dan Irene, 2011:11). Berdasarkan lima jari, peserta mengenal aset (kode 1), liabilitas (kode 2), ekuitas (kode 3), pendapatan (kode 4) dan beban (kode 5). Mulai dari titik inilah, peserta mulai diajak memahami penggunaan kode satu sampai dengan lima. Penggunaan kode akan mempermudah pengelola mengenali akun yang akan memiliki saldo normal di sisi debit atau di sisi kredit. Peserta juga memperoleh informasi tambahan, bahwa debit atau kredit tidak sama dengan penerimaan atau pengeluaran.

Memasuki materi penyusunan laporan keuangan, suasana semakin mencair. Setiap penyajian materi selalu diawali dengan tanya jawab yang ringan. Misalnya, pemateri menanyakan kasus berikut: Tuan A membeli 10 buah pulpen seharga $\mathrm{Rp}$ 1000 per buah. Tuan A berhasil menjual 8 buah pulpen seharga Rp 1200 per buah. Apakah tuan A memperoleh kerugian ataukah keuntungan?. Pertanyaan ini memancing diskusi yang memeriahkan suasana pelatihan. Kasus ini membuka peluang peserta untuk memahami konsep "matching", "laba/rugi", dan "persediaan barang". Pemahaman atas kasus ini digunakan untuk menyusun laporan keuangan sekaligus memahami konsep dasar akuntansi lainnya.

Pelatihan ini memberikan ilmu yang berharga, bagi peserta dan pemateri. Peserta membagi pengalaman mengenai praktik pengelolaan BUMDes yang telah 
mereka lakukan, sedangkan pemateri mengkaitkan dengan standar akuntansi dan peraturan kementerian yang berlaku. Untuk keberlanjutan dari kegiatan ini, peserta mengharapkan pendampingan yang mendalam pada saat penyusunan laporan keuangan. Kebersamaan peserta dan pemateri diakhir pertemuan terlihat dalam gambar 4, dengan mengucapkan "kalau ada sumur di ladang, boleh kita menumpang mandi, kalau ada umur panjang, kami tunggu di BUMDes kami".

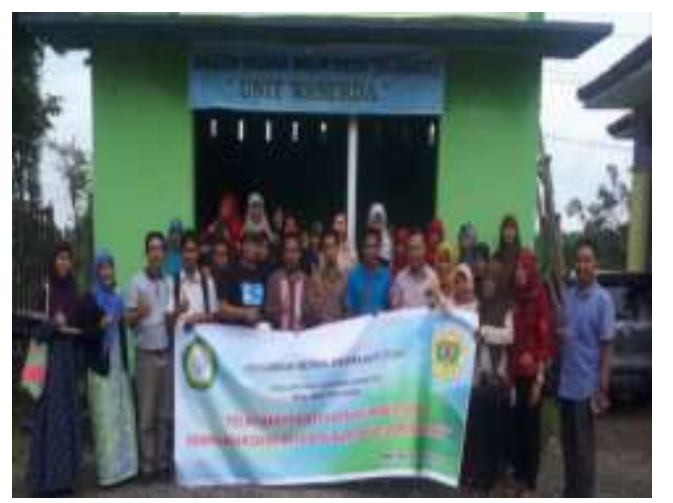

Gambar 3. Kebersamaan di akhir sesi pelatihan

\section{KESIMPULAN DAN SARAN}

\section{Kesimpulan}

Kegiatan pengabdian kepada masyarakat yaitu, pelatihan penyusunan laporan keuangan BUMDes di Kabupaten Lombok Barat telah dilaksanakan. Kegiatan bertempat di kantor desa Ombe Baru, Kecamatan Kediri Kabupaten Lombok Barat. Hasil dari kegiatan pengabdian masyarakat ini, peserta dapat memiliki pengetahuan baru mengenai konsep dasar penyusunan laporan keuangan. Hal mendasar yang wajib dipahami oleh peserta antara lain pengertian "akun", memberikan "kode akun" dan memahami "debet dan kredit" menggunakan lima jari.

\section{Saran}

Pengadian kepada masyarakat ini memliki tingkat kesulitan dari sisi ragam jenis usaha BUMDes. Keterbatasan ini dapat dikurangi dengan kunjungan langsung ke lokasi BUMDes atau menyusun buku pedoman akuntansi bagi BUMDes yang sesuai dengan SAK-EMKM.

\section{UCAPAN TERIMA KASIH}

$$
\text { Ucapan terimakasih kami }
$$

haturkan kepada Lembaga Penelitian dan Pengabdian Kepada Masyarakat Universitas Mataram, atas kesempatan yang diberikan untuk melaksanakan kegiatan ini. Tak lupa, ucapan terimakasih tak terhingga bagi Kepala Desa Ombe Baru, Kecamatan Kediri 118

Available online : http://abdiinsani.unram.ac.id 
kabupaten Lombok Barat, atas kesempatan yang diberikan untuk menggunakan ruang pertemuan bagi seluruh peserta, serta Koordinator pendamping BUMDes Kabupaten Lombok Barat yang telah melakukan koordinasi demi terlaksananya kegiatan ini. Semoga bermanfaat.

\section{DAFTAR PUSTAKA}

Anonim, 2015, Peraturan Menteri Desa, Pembangunan Daerah Tertinggal dan Transmigrasi Republik Indonesia, Nomor 4 Tahun 2015 tentang Pendirian, Pengurusan dan Pengelolaan,
Pembubaran Badan Usaha Milik Desa.

Ikatan Akuntan Indonesia, 2016, Standar Akuntansi Keuangan Entitas Mikro, Kecil dan Menengah, penerbit Salemba Empat, Jakarta.

Putra, Surya Anom, 2015, Buku 7: Badan Usaha Milik Desa: Spirit Usaha Kolektif Desa, Kementerian Desa, Pembangunan Daerah Tertinggal dan Transmigrasi Republik Indonesia, Jakarta.

Warsono, Sony dan Irene Natalia, 2011, Akuntansi Pengantar 1: Sistem Penghasil Informasi Keuangan, ABPublisher, Yogyakarta. 